\title{
Jambi and Palembang clay soil stabilization for pavement matrix in road construction by using Portland cement type I
}

\author{
Wawan Kuswaya ${ }^{1, *}$, Wahyudi Marsiano ${ }^{1}$, Syafalni Syafalni ${ }^{1}$, and Jonbi ${ }^{2}$ \\ ${ }^{1}$ Department of Civil Engineering, Institut Sains dan Teknologi Nasional, Jakarta, Indonesia \\ ${ }^{2}$ Department of Civil Engineering, Universitas Pancasila, Jakarta, Indonesia
}

\begin{abstract}
The need for a pavement matrix in road construction, especially in Sumatra area, is now more difficult and expensive because the deposit materials are concentrated in Java and most of them are not available. For this reason, soil stabilization is a way out of this problem. On this basis it is necessary to conduct stabilization research with highly active stabilization material by using Portland cement type I. The soil to be stabilized is clay soil which is derived from the areas of Jambi and Palembang and which has a low CBR value less than the requirement for sub base or pavement (< $10 \%$ ), with the expected CBR value of stabilization to be suitable for road construction. This research covers physical and soil mechanical properties which are compaction parameter and CBR value with 3 days of dry curing time and 4 days of soak curing time using ASTM test procedure. Variations of cement addition were used of $6 \%, 8 \%$, and $10 \%$ for the clay soil from Palembang and $8 \%, 10 \%$, and $12 \%$ for the clay soil from Jambi, by percentage of dry weight of the sample test. The results of this study showed that the CBR value significantly increased with the addition of cement, with Palembang soil CBR value rising from $3.46 \%$ to $130.74 \%$ and Jambi soil CBR value rising from $7.20 \%$ to $206.43 \%$ respectively.
\end{abstract}

\section{Introduction}

The lack of accessibility of high-quality materials and the increased costs associated with the use of these materials have necessitated engineers to use local soils. In such cases, the subgrade soil and its properties are important in the design of pavement structure as it has to give adequate support to the pavement, for which it has to possess sufficient strength and stability even under adverse traffic and climatic condition. The subgrade soil improvement behaved satisfactorily in many conditions. The Subgrade soil improvement can be defined as the procedure of increasing shear strength parameters and decreasing the permeability and compressibility of the soil. Different methods can be used to improve the geotechnical properties of the problematic soils, one of which is using additives. Stabilization is achieved by the addition of proper percentages of cement, lime, fly ash, bitumen, or combinations of these materials to the soil. The selection of type and determination of the percentage of

\footnotetext{
* Corresponding author: wawankuswaya@istn.ac.id
} 
additive to be used is dependent upon the soil classification, and the degree of improvement in soil quality desired [1-3].

Clay soils generally exhibit undesirable engineering properties. They tend to have low shear strength, which reduces further upon wetting or other physical disturbances. They can be plastic and compressible, expand when wetted, and shrink when dried. Some types expand and shrink greatly upon wetting and drying, thereby exhibiting some very undesirable features. Cohesive soils can flow over time under constant load, especially when the shear stress is approaching its shear strength, making them prone to sliding. They develop large lateral pressures and tend to have low resilient modulus values. For these reasons, clay soils are generally poor materials for foundations, but if they are to be utilized, their properties may need to be improved in some cases by soil stabilization. Stabilization is the process of blending and mixing materials with soil to improve the properties of the soil. The process may include the blending of soils to achieve a desired gradation or the mixing of commercially available additives that may alter the gradation and improve the engineering properties of soil, thus making it more stable [4].

Soil stabilization involves the use of stabilizing agents (binder materials) in weak soils to improve its geotechnical properties such as compressibility, strength, permeability, and durability. The components of stabilization technology include soils and or soil minerals and a stabilizing agent or binders. Soil stabilization can be explained as the alteration of the soil properties by chemical or physical means to enhance the Engineering quality of the soil. Natural soil is both a complex and variable material, yet because of its universal availability and its low-cost winning, it offers the opportunity for skillful use as an engineering material. The chief properties of a soil with which the construction engineer is concerned are volume stability, strength, permeability, and durability [5].

Soil used as the basis for the construction of highways in Indonesia is usually a finegrained soil, where the properties of clay are more dominant than that of silt. In road construction, land base is a very decisive layer of long-term road damage. Good quality and ugly of this layer, one of which is influenced during compaction work. This can be seen from the density, with the density measure reflected from the value of the dry content weight (d) or the value of the pore number (e). The density when compacting can be maximized if the moisture content of the soil is at optimum compaction (optimum moisture content) and also with the optimum energy of the compaction.

The performance of a pavement depends upon the quality of subgrades and sub-bases. A stable subgrade and properly draining sub-base help produce long-lasting pavement. A high level of spatial uniformity of a subgrade and sub-base regarding key engineering parameters such as shear strength, stiffness, volumetric stability, and permeability is vital for the effective performance of the pavement system. A number of environmental variables such as temperature and moisture affect these geotechnical characteristics, both in the short and long term. The subgrade and sub-base work as the foundation for the upper layers of the pavement system and are vital in resisting the detrimental effects of climate, as well as static and dynamic stresses that are generated by traffic. Furthermore, there has been a significant amount of research on stabilization/treatment techniques, including the use of recycled materials, geotextiles, and polymer grids for the design and construction of uniform and stable subgrades and sub-bases [3,6]. The objective of this study seeks to determine the geotechnical properties of clay soil stabilized with cement using Portland cement type I through laboratory tests using the California bearing ratio (CBR) test.

\section{Materials and methods}

In order to experiment the determination of material properties, a series of tests were performed using the ASTM procedures as follows. 
1. Prepare soil samples and tools in the laboratory. The clay soil used in this study was obtained from Palembang and Jambi.

2. Conduct preliminary research by doing soil properties test with Atterberg boundary test, soil gradient test with sieve and hydrometer test, compaction test with a modified method to obtain optimum moisture content and maximum dry density by using ASTM D-698[7]. Test results can be seen in Table 1, 2 and 3.

Table 1. Atterberg boundary values.

\begin{tabular}{|c|c|c|}
\hline Atterberg limit & Palembang & Jambi \\
\hline Liquid Limit & $68.78 \%$ & $72.12 \%$ \\
\hline Plastic Limit & $38.72 \%$ & $32.72 \%$ \\
\hline Plasticity Index & $34.05 \%$ & $40.09 \%$ \\
\hline Classification & $\mathrm{CH}$ & $\mathrm{CH}$ \\
\hline
\end{tabular}

Table 2. Particle distribution.

\begin{tabular}{|c|c|c|}
\hline Type of soil & Palembang & Jambi \\
\hline Gravel & $0.00 \%$ & $0.00 \%$ \\
\hline Sand & $3.49 \%$ & $13.61 \%$ \\
\hline Silt & $61.52 \%$ & $33.44 \%$ \\
\hline Clay & $35.00 \%$ & $52.95 \%$ \\
\hline
\end{tabular}

Table 3. Modified compaction test.

\begin{tabular}{|c|c|c|}
\hline Property & Palembang & Jambi \\
\hline $\mathrm{W}_{\mathrm{optm}}$ & $17.35 \%$ & $26.58 \%$ \\
\hline $\mathrm{Jdmax}$ & $1.692 \mathrm{t} / \mathrm{m}^{3}$ & $1.482 \mathrm{t} / \mathrm{m}^{3}$ \\
\hline
\end{tabular}

3. Conduct the California Bearing Ratio Test (CBR test) is the penetration test developed by the California State Highway Department (USA) for evaluating the bearing capacity of subgrade soil for design of flexible pavement. The CBR rating was developed for measuring the load-bearing capacity of soils used for building roads. The CBR can also be used for measuring the load-bearing capacity of unimproved airstrips or for soils under paved airstrips. The harder the surface and the higher of the CBR rating [5]. The results are presented in Table 4.

Table 4. Results of initial CBR test.

\begin{tabular}{|c|c|c|}
\hline & Palembang & Jambi \\
\hline Soaked & $3.46 \%$ & $7.20 \%$ \\
\hline
\end{tabular}

4. Conduct the compaction series tests for CBR were performed by using three variations of compactions $(6 \%, 8 \%, 10 \%)$ and three variations of cement mixture $(8 \%, 10 \%, 12 \%)$ 
for Palembang and Jambi soils respectively based on the procedures from ASTM D 1883[8]. The different variations were due to the initial value of the CBR test for sample locations. The treated samples were cured by sprinkling for 3 days at room temperature for CBR unsoaked (dry curing) tests and immersed for 4 days in cement stabilization for CBR soaked tests.

\section{Results and discussion}

\subsection{Results of Palembang soil testing}

Through laboratory tests, some results were obtained. The CBR values of treated samples with Portland cement type I increased. Figure 1 shows the result of the stress test of the compaction of the soil with the cement stabilized soil of $6 \%, 8 \%$, and $10 \%$.

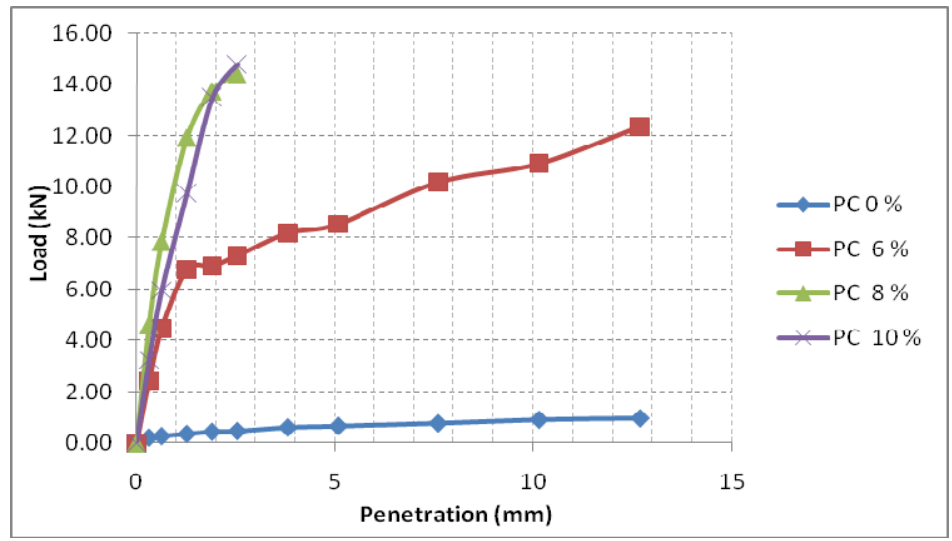

Fig. 1. Graph of the relationship between penetration in $(\mathrm{mm})$ vs pressure load in $\mathrm{kN}$ for Palembang soil (soaked).

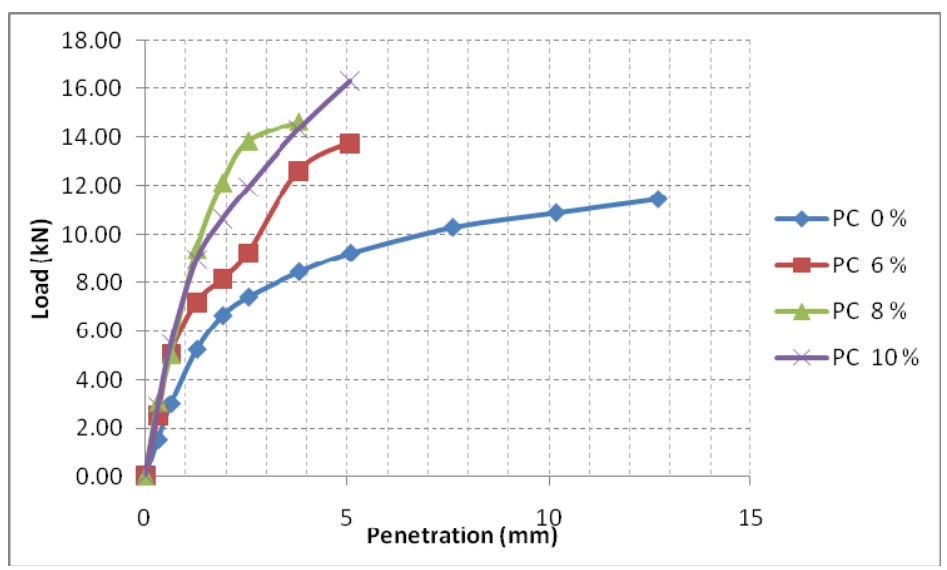

Fig. 2. Graph of the relationship between penetration in $(\mathrm{mm})$ vs pressure load in $\mathrm{kN}$ for dry condition (unsoaked) of soil sample of compaction test result of Palembang soil.

Fig. 2 shows the compression test results for the compacted soil by modified, unmixed ground $(\mathrm{Pc})$ and cement stabilized soil from $6 \%, 8 \%$ and $10 \%$, with the sample condition cured for 3 days (unsoaked test). As can be seen from the figures or the relationship 
between load and penetration graphs (Fig. 1, and Fig. 2), it can be seen that regarding the stiffness level of the stabilized soil with soaked and unsoaked treatment, soaked stabilized soil has a more rigid tendency compared to the unsoaked. This shows an excellent chemical reaction between clay soil and cement.

\subsection{Results of Jambi soil testing}

Fig. 3 shows the compression of the test result of the modified soil compaction sample with cement stabilized soil of $8 \%, 10 \%$ and $12 \%$. Fig. 4 below is a graph of the compression test results for the compacted soil compaction sample by modified, unmixed ground (Pc) and cement stabilized soil of $8 \%, 10 \%$ and $12 \%$.

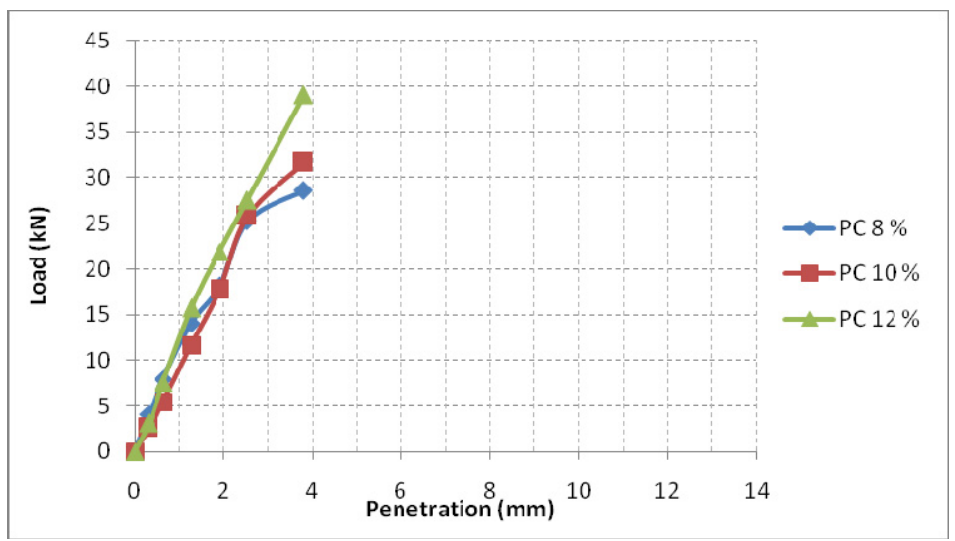

Fig. 3. Graph of the test results for the relationship between penetration in $\mathrm{mm}$ against pressure load in $\mathrm{kN}$ for Jambi soil (soaked).

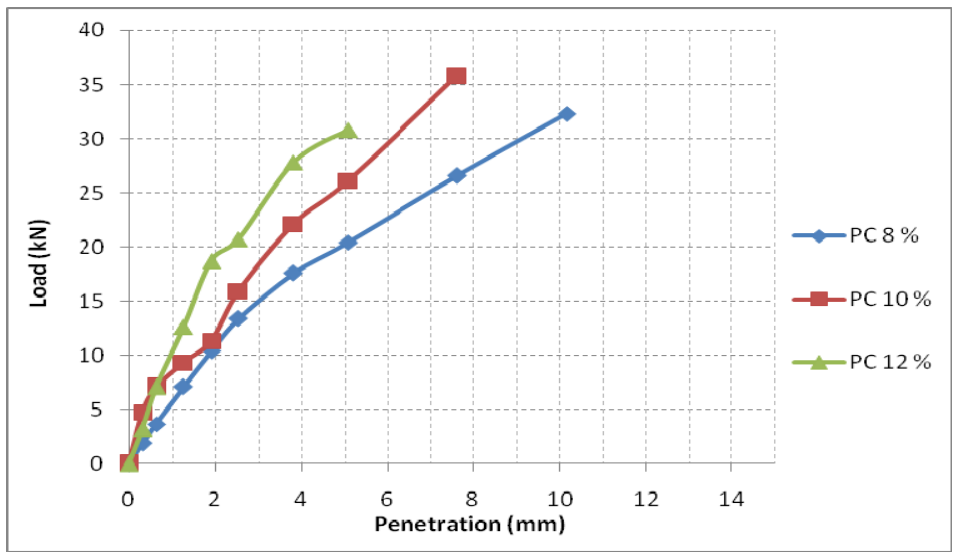

Fig. 4. The compression test results for the compacted soil compaction sample by modified method (unsoaked).

According to Fig. 3 and, the relationship between the load and penetration regarding the level of stiffness of the stabilized soil with soaked and unsoaked treatment, soaked stabilized soil has a more rigid tendency compared to those unsoaked, which shows a good chemical reaction. It is worth noting Jambi clay soil strength has a higher value than that of Palembang clay soil. The condition was due to the CBR value with stabilizer content in 
Jambi soil my stern from its high plasticity index and high clay content that will influence by the moisture content of the soil [9].

\subsection{Discussion of the CBR test results}

Based on the graphs above (Fig. 1, 2 for Palembang) and (Fig 3, 4 for Jambi), the CBR value can be calculated using the value of comparison between compacted load value when there is pressure of compacted load into the soil layer compared to standard load is $3000 \mathrm{lb}$ $(1362.4 \mathrm{~kg})$ for 0.10 inch $(2.564 \mathrm{~mm})$ penetration and $4500 \mathrm{lb}(2043.6 \mathrm{~kg})$ for $0.2 \mathrm{inch}$ $(5.128 \mathrm{~mm})$ penetration.

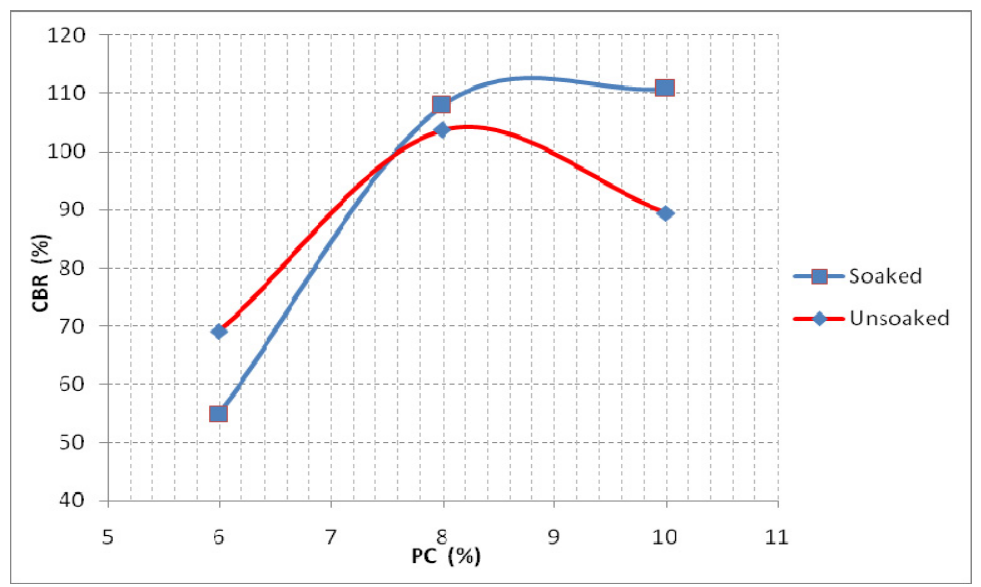

Fig. 5. Graph of the relationship between the CBR value (\%) and the percentage of cement mix (PC) with two dry testing conditions (unsoaked and soaked) for Palembang clay soil.

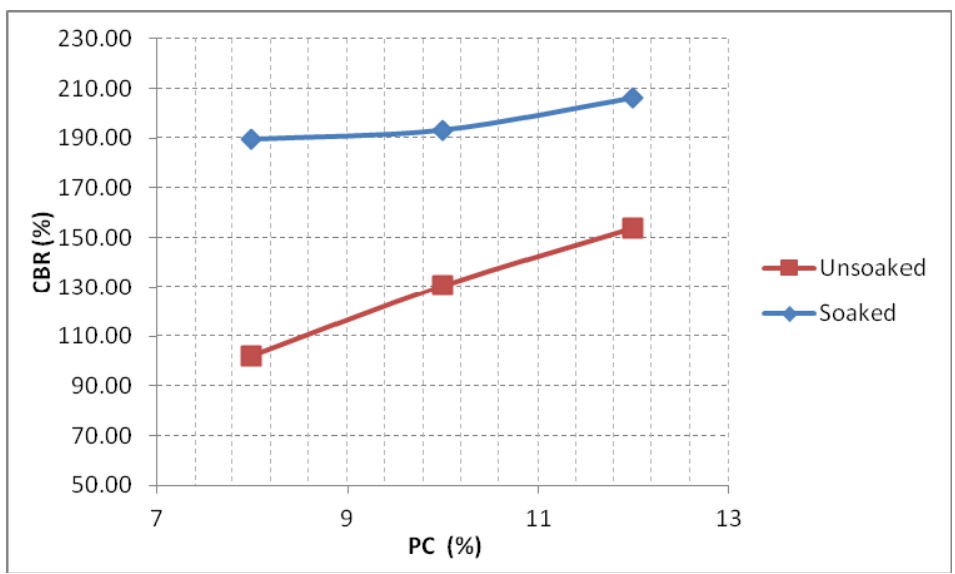

Fig. 6. Graph of the relationship between the CBR value (\%) on the percentage of cement mix (PC) with two conditions of dry testing (unsoaked and soaked) for Jambi clay soil.

Based on the compression of the compacted soil samples by the modified method, the condition of the sample is unsoaked or soaked for the sample with $0 \%$ cement and with the addition of $6 \%, 8 \%$ and $10 \%$ cement (Palembang sample) and $8 \%, 10 \%$ and $12 \%$ cement (Jambi samples), the soil from Palembang and Jambi with cement stabilization shows that the CBR value obtained is very high in proportion to the addition of cement as can be seen in Fig. 5 and 6 below. The CBR range from 55 to 206\% up to the addition of $8 \%$ cement of 
the CBR value ranges ranging from 102 to $189 \%$. The highest CBR obtained from the Jambi soil samples. Samples between soaked and unsoaked have higher CBR values.

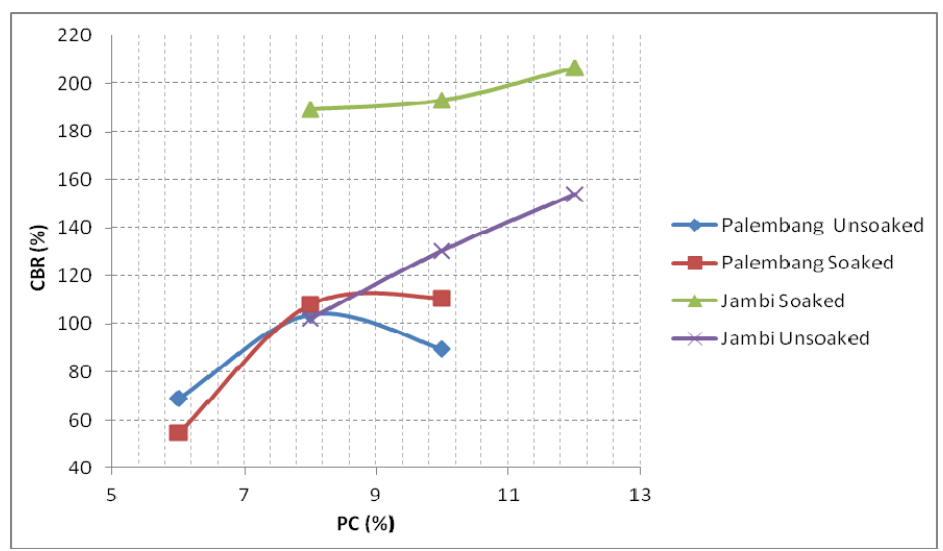

Fig. 7. The combined graph of the Pelembang and Jambi soil samples, the relation between the CBR values in (\%) and the percentage of cement mix (PC) with unsoaked and soaked condition.

Fig. 7 highlights the test results of both soils, which shows Jambi soaked soil samples obtained by far the best results with a CBR value of 189 at $8 \%, 192$ at $10 \%$ and 206 at $12 \%$. This is due to the chemical bond produced by the reaction of Portland cement type 1 which increased the strength of treated soil. The reason for this is that Jambi soil clay particle distribution is higher than Palembang Soil (Table 2) [10].

Table 5. Comparison CBR results for soil stabilized with Cement from Texas soil, USA [10] and Portland Cement type I from Palembang and Jambi soil samples.

\begin{tabular}{|c|c|c|c|c|c|}
\hline Soil ID & $\begin{array}{c}\text { Stabilizer } \\
\text { dosage (\%) }\end{array}$ & Stabilizer & $\begin{array}{l}\text { Unsoaked } \\
\text { CBR (\%) }\end{array}$ & $\begin{array}{c}\text { Soaked CBR } \\
(\%)\end{array}$ & $\begin{array}{l}\text { Initial CBR } \\
\text { (\%), soaked }\end{array}$ \\
\hline \multirow[t]{2}{*}{ Texas $1^{*}$} & 6 & \multirow{2}{*}{$\begin{array}{c}\text { Portland } \\
\text { Cement } \\
\text { Type I }\end{array}$} & 190 & 200 & \multirow[t]{2}{*}{4} \\
\hline & 9 & & 190 & 260 & \\
\hline \multirow[t]{2}{*}{ Texas $2^{*}$} & 6 & \multirow{2}{*}{$\begin{array}{c}\text { Portland } \\
\text { Cement } \\
\text { Type I }\end{array}$} & 130 & 100 & \multirow[t]{2}{*}{4} \\
\hline & 9 & & 220 & 190 & \\
\hline \multirow[t]{3}{*}{ Palembang } & 6 & \multirow{3}{*}{$\begin{array}{c}\text { Portland } \\
\text { Cement } \\
\text { Type I }\end{array}$} & 69 & 55 & \multirow[t]{3}{*}{3.46} \\
\hline & 8 & & 103 & 108 & \\
\hline & 10 & & 90 & 112 & \\
\hline \multirow[t]{3}{*}{ Jambi } & 8 & \multirow{3}{*}{$\begin{array}{c}\text { Portland } \\
\text { Cement } \\
\text { Type I }\end{array}$} & 102 & 189 & \multirow[t]{3}{*}{7.20} \\
\hline & 10 & & 130 & 192 & \\
\hline & 12 & & 152 & 206 & \\
\hline
\end{tabular}

Note: ${ }^{*}$ The results of Texas, USA was obtained from reference about report from Research \& Development Bulletin, Portland Cement Association [10].

The comparison of CBR values for both unsoaked and soaked stabilized specimens were measured for 4 days. The results for all soils are given in Table 5, which include two 
types of Texas, USA soil for comparison. The results of the CBR test of soil for comparison was getting from the experiments in Texas, USA for the unsoaked and soaked stabilized specimens were measured after 91 days [9]. In general, the soaked SBR values are higher than unsoaked values for cement stabilized soil, except both the unsoaked results from Texas 2 and unsoaked Palembang soil at 6\%. Jambi soil showed higher CBR values than Palembang soil. Soil mixed with cement can be used for sub-bases layer and the base layer of pavement.

\section{Conclusions}

The soil of Palembang and Jambi included in this research is suitable for the stabilization of cement with the achievement of high CBR value. With an $8 \%$ cement mixture, the value is $102 \%$ to $189 \%$. The sample immersion that has been done soaked better than unsoaked. From the CBR value of the clay soil that has been stabilized with minimal mixed cement, it can be seen that the CBR value achieved is quite high for the clay soil from Palembang and Jambi so in theory this stabilization of clay soil can be used to replace the sub-base layer and base layer.

\section{References}

1. R.A. Shooshpasha, R.A. Shirvani. Geomech. Eng. 8, 1 (2015)

2. G. Kattimani, H.M. Nethravathi, O. Priyanka, A.S. Amaravati, S. Sanjeev, IJIRSET 6, 4 (2015)

3. S. Marathe, A. Kumar, Avinash, IJIRSET 4, 12 (2015)

4. J. Olufowobi, A. Ogundoju, B. Michael, O. Aderinlewo. JESTEC 9, 5 (2014)

5. P. Tamang, S. Gurung, R. Basnett, S. Sharma, R. Pandit. IJETT 33, 8 (2016)

6. V.R. Schaefer, D.J. White, H. Ceylan, L.J. Steven. Design guide for improved quality of roadway subgrades and subbases IHRB project TR-525 (Iowa State University, Iowa, 2008)

7. ASTM. Standard Test Methods for Laboratory Compaction Characteristics of Soil using Standard Effort (12 $400 \mathrm{ft}$-lbf/ft $\left.600 \mathrm{kN}-\mathrm{m} / \mathrm{m}^{3}\right)$ ) ASTM D 698 (ASTM International, 2012)

8. H. Darmawan, Uji CBR. ASTM D1883, UPI Lab, Bandung.

9. S. Bhattacharja, J.I. Bhatty. Comparative performance of Portland cement and lime stabilization of moderate to high plasticity clay soils RD 125 (PCA, Illinois, 2003)

10. A. M. Mosa, A.H. Taher, A. L. Al-Jaberi. Case Stud. Con. 7 (2017) 